\title{
CONFERENCIAS
}

\section{A AMIGDALOIDECTOMIA NO TRATAMENTO DAS ALUCINAÇÕES AUDITIVAS}

\author{
WALTER FREEMAN *
}

Embora as operaçōes sôbre os lobos frontais forneçam bons resultados em número bastante grande de doentes com transtornos mentais, existem casos em que tais operações não são coroadas de sucesso. Procurando as causas dêstes insucessos, chega-se à conclusão de que grande parte dêles ocorre em enfermos que sofrem de alucinações; êstes sintomas persistem não importa qual seja o plano de secção das radiações tálamo-frontais. Por essa razão, nos casos em que as alucinações ocupam lugar preponderante na sintomatologia da psicose, pode-se dizer que o paciente não se beneficiará com a lobotomia frontal. Possivelmente, nesses casos, a base fisiopatogênica da psicose não se encontra no lobo frontal e sim no lobo temporal.

A primeira operação de psicocirurgia, feita por Burckhardt em 1889, consistiu em ressecção de parte do lobo temporal esquerdo (topectomia). Em 1947, após a divulgação das intervenções sôbre o lobo frontal em psicocirurgia, Obrador Alcalde tentou algumas operações sôbre os lobos temporais. Outros cirurgiões (PenfieId, Bailey, entre outros) verificaram que a extirpação de uma parte do lobo temporal melhora a sintomatologia de casos de epilepsia psicomotora nos quais o eletrencefalograma permite evidenciar a presença de foco anormal; o mais importante nestas observações foi a verificação de que em alguns casos a aura epiléptica consistia em alucinação auditiva.

Por outro lado, é mister analisar outro aspecto das alucinações auditivas, ou seja o aspecto motor. As idéias que surgem no cérébro devem cristalizar-se em uma matriz motora para transformar-se em têrmos de linguagem. Procurando a sede desta transformação, nossa atenção se voltou para o núcleo amigdalóide, situado na superfície interna do lobo temporal, entre o pé do hipocampo e o núcleo caudado. O núcleo amigdalóide é um centro com células multipolares, cujo tamanho representa um têrmo médio entre o das células do núcleo caudado e o das células grandes do globo pálido. As conexões dêsse núcleo com outras regiões do cérebro são pouco conhecidas, embora existam numerosas fibras que parecem penetrar no córtex temporal.

Trabalho traduzido para o português por $O$. Lange.

* Antigo Professor de Neurologia na Universidade de Washington (U.S.A.). 
O núcleo amigdalóide é considerado como parte do aparêlho olfativo. Entretanto, nos cetáceos, como a baleia e o delfim, que não possuem aparêlho olfativo, o núcleo amigdalóide tem grandes dimensões. Estes animais se orientam pelo som; seus órgãos auditivos se apresentam com um desenvolvimento máximo e seus nervos auditivos são maiores que seus nervos ópticos; os colículos inferiores do porco marinho chegam a apresentar a forma e o tamanho de uma cereja. É sabido que todos os cetáceos emitem sons muito altos, fora dos limites da acústica humana; êstes animais podem, também, ouvir sons muito altos, de acôrdo com as observações de navegantes com o emprêgo de instrumentos de eco supersônico: quando o instrumento emite seus sons, os cetáceos fogem.

Experiências com cetáceos, sôbre a emissão e recepção dessas vibrações superagudas estão fora de nossas possibilidades. Entretanto, o morcêgo também se orienta pelo som; êste animal, quando em vôo, com os olhos vendados, evita os obstáculos; não pode evitá-los, porém, quando sua bôca e suas orelhas são vedadas. $O$ morcêgo emite sons de freqüência entre 30.000 e 50.000 vibrações por segundo; seu aparêlho vocal é muito muscularizado e seu aparêlho auditivo tem grandes dimensões. O núcleo amigdalóide do morcêgo tem quase o mesmo tamanho que $o$ núcleo caudado.

Cremos que o núcleo amigdalóide do homem funciona como um aparêlho de transformação de sensações auditivฯs no ato de falar. Funciona como um núcleo extrapiramidal, da mesma forma que o núcleo caudado e o putâmen atuam nos movimentos automáticos dos membros. O núcleo amigdalóide tem conexões apenas indiretas com os músculos da fala; provàvelmente, sua ação se faz através do tálamo. Êsse núcleo pode ser extirpado bilateralmente sem que se produzam alterações no funcionamento dos músculos da fala ou da expressão; a voz do paciente continua invariável, com a mesma altura e com qualidade e ressonância normais. Extirpado o núcleo amigdalóide, entretanto, desaparecem os automatismos que se fazem à custa dessa musculatura, provàvelmente por interrupção dos impulsos aferentes auditivos. Assim, a extirpação do núcleo amigdalóide seria indicada em casos de alucinações auditivas.

Tivemos ocasião de comprovar, diretamente, o efeito da amigdaloidectomia na supressão dos movimentos automáticos da língua e dos lábios em um enfêrmo com alucinações auditivas contínuas.

ObServação - Paciente do sexo masculino, de 22 anos, estudante. Dizia, textualmente, "pessoas me ordenam que mova meus lábios". Realmente, êste paciente em qualquer momento que fôsse observado movia os lábios, mas sem fonação, como se estivesse cochichando constantemente; quando se mandava que fechasse a bôca, podia suprimir os movimentos, os quais reiniciava imediatamente, colocando a mão em frente da bôca. O enfêrmo vinha sofrendo há 3 anos, sem apresentar variaçōes do quadro, apesar dos tratamentos com insulina e eletrochoque a que fôra submetido. Freqüentemente falava em voz alta, mas afirmava não poder repetir o que lhe diziam as "vozes espirituais".

Repetimos as provas de Gould, ao registrar suas produções subvocais com gravador de fita magnética. O paciente foi colocado em quarto à prova de som, com um microfone colocado entre a bôca e o ouvido; entre o microfone e o gravador foi colocado um amplificador. Com o quarto fechado, observamos o paciente duran- 
te uma hora através de pequena janela e, durante êsse tempo, registramos continuamente seus cochichos. Quando o paciente não era molestado, começava a falar a si mesmo em voz baixa, sòmente com os lábios e a lingua; as palavras eram quase incompreensíveis, sendo emitidas muito ràpidamente, com deformações, contrações de sílabas, pausas e, às vêzes, ruídos guturais. As vêzes, ria em voz alta, voltava-se no leito, gesticulava e escrevia no ar com o dedo.

Após a prova ouvimos a gravação obtida com o objetivo de averiguar a opiniāo do paciente que não mostrou qualquer interêsse por suas produçōes subvocais. Disse, quando insistimos, que entendera tudo o que fôra gravado. Informou que uma máquina fazia mover os lábios, mas não pôde explicar o fenômeno nem o sentido da voz registrada.

Amigdaloidectomia - Com o paciente sentado, o cirurgião injetou novocaina na região temporal esquerda; após a abertura do crânio $(3 \times 4 \mathrm{~cm})$, a dura-máter foi seccionada, sendo exposta a córtex do lobo temporal. A superfície da segunda circunvolução temporal foi coagulada com termocautério, sendo aberta via de acesso de $12 \mathrm{~mm}$ por meio de um aspirador, atrás da crista esfenoidal e a $12 \mathrm{~mm}$ acima do assoalho da fossa média. Mediante aspiração e retração, o cirurgião penetrou na substância branca até o corno temporal do ventrículo lateral, com o que houve saida de liqüido cefalorraquidiano. Alargando a abertura, o cirurgiāo distinguiu, na parte anterior, uma eminência cinzenta da qual foi ressecada uma pequena parte para identificação histológica, sendo, depois, aspirado o restante do núcleo até seus limites. No fundo da incisão foi possivel distinguir grande fascículo de côr branca, o tracto óptico.

Operação semelhante foi feita no lado oposto na semana seguinte.

Evolução - Logo depois da primeira operação já não foram mais observados movimentos dos lábios do paciente. Entretanto, não foi verificada quase nenhuma mudança em seu estado psíquico. O paciente sempre se mostrou reservado, inclinado à introversão; não apresentou interêsse pelos seus enfermeiros ou por seus médicos. Não sabia o nome do hospital, mas cremos que seu estado de indiferença era a base de sua desorientação aparente. Após as intervenções o paciente admitiu que as "vozes espirituais" não mais continuavam a atormentá-lo e que a "máquina não continuava movendo seus lábios". Mostrou-se indiferente a tudo que o rodeava até o dia da alta, 8 dias após a operação final. Quando foi repetida a experiência no quarto fechado, não pronunciou qualquer palavra. Sua indiferença impediu a utilização dos vários testes de inteligência, tanto antes como depois das intervenções. Não apresentou os fenômenos que habitualmente ocorrem após a lobectomia frontal, nem mesmo se queixou de cefaléia.

Esste paciente parecia apresentar uma forma hebefrênica de esquizofrenia, com muitas alucinações auditivas. Cremos que as "vozes espirituais" fôssem produzidas por mecanismo fisiopatogênico no qual tomava parte o núcleo amigdalóide. Quando êste foi extirpado, as alucinaçōes desapareceram, bem como os movimentos dos lábios. O paciente continuou esquizofrênico, mas livre de um dos sintomas principais.

15. Main Street - Los Altos, California, U.S.A. 